\title{
PREPARATION AND PHYTOTOXICITY OF SORGOLEONE ANALOGUES
}

Luiz Cláudio de Almeida Barbosa*, Maria Lúcia Ferreira e Antonio Jacinto Demuner

Departamento de Química, Universidade Federal de Viçosa, 36571-000 - Viçosa-MG

Antonio Alberto da Silva e Rita de Cássia Pereira

Departamento de Fitotecnia, Universidade Federal de Viçosa, 36571-000 - Viçosa-MG

Recebido em 24/8/00; aceito em 16/5/01

PREPARATION AND PHYTOTOXICITY OF SORGOLEONE ANALOGUES. 3,5-Dimethoxybenzylic alcohol was converted into the 2-acetoxy-5-methoxy-3-(pent-1-yl)-1,4-benzoquinone (12), in seven steps, with an overall yield of $14.6 \%$. The natural quinone sorgoleone (1) was isolated from Sorghum bicolor and converted into the corresponding quinone (13) having a saturated side chain. The selective effects of these compounds $(\mathbf{1}, 12$ and 13), at the dose of $5.6 \mu \mathrm{g}$ of a.i./ g of substrate, on the growth of Cucumis sativus, Lactuca sativa, Desmodium tortuosum, Hyptis suaveolens and Euphorbia heterophylla were evaluated. All three compounds caused some inhibition on the root growth of the test plants $(0.0$ $69.19 \%$ ) with the aerial parts less affected. The results showed that the triene unit of the sorgoleone side chain is not essential for the phytotoxicity and also the synthetic quinone was as active as the natural product.

Keywords: quinones; herbicides; weed.

\section{INTRODUCTION}

The allelopathic effect caused by sorghum species has been reported by several investigators ${ }^{1-4}$. Several biologically active compounds having plant growth inhibitory activity, like $p$ hydroxybenzaldehyde, vanillic acid, $p$-coumaric acid, and syringic acid have been found in the aqueous washings from sorghum $^{5,6}$.

Studies carried out by Netzly and Butler $(1986),{ }^{7}$ on the chemical composition of the hydrophobic root exudate of sorghum, led to the isolation and identification of sorgoleone (1) and dihydrosorgoleone (2), as the major constituents. In a further work Netzly et al. $(1988)^{8}$ identified three other minor $p$-benzoquinones, structurally similar to sorgoleone (Figure 1).<smiles>C=CC/C=C/C/C=C/CCCCCCC1=C(O)C(=O)C=C(OC)C1=O</smiles>
(1): Sorgoleone<smiles>C=CC/C=C/C/C=C/CCCCCCCc1c(O)c(O)cc(OC)c1O</smiles>

(2): Dihydrosorgoleone

Figure 1. Compounds found in the root exudate of Sorghum.

It has been shown that the hydrophylic root exudate of sorghum at a concentration of $10 \mathrm{mg} / \mathrm{mL}$ caused $85 \%$ inhibition on the root elongation in lettuce ${ }^{7}$.

Dihydrosorgoleone (2) is active as a germination stimulant of witchweed (Striga asiatica L. Kuntz STRLU) ${ }^{8,9}$. It has been

*e-mail: 1cab@mail.ufv.br demonstrated that sorgoleone is very active at inhibiting the growth of several grass weeds at the concentration of only $10 \mu \mathrm{M}^{10}$. Sorgoleone affects the mitochondrial respiration ${ }^{11}$ and it is an effective photosynthesis inhibitor ${ }^{12,13}$.

Despite all the information available on the sorgoleone activity, the potential use of this compound as a model for the preparation of new herbicides has not been explored. Thus, the aim of this work was to develop a synthetic route that would allow the preparation of several quinones for biological evaluation. We also investigated the influence of the skipped triene unit on the sorgoleone side chain of the biological activity.

\section{EXPERIMENTAL}

Reagents and solvents were purified, when necessary, according to the usual procedures described in the literature ${ }^{14}$. Flash column chromatography was performed using Crosfield Sorbil C60 $(32-63 \mu \mathrm{m})$. The melting points were determined on an electrothermal digital apparatus with correction. Infrared spectra were recorded on a Mattson Instruments FTIR 3000 grating spectrometer, using potassium bromide disk or sodium chloride liquid film, scanning from 625 to $4000 \mathrm{~cm}^{-1}$. Mass spectra were recorded under electron impact $(70 \mathrm{eV})$ conditions, using a VG ANALYTICAL ZAB-IF spectrometer. ${ }^{1} \mathrm{H}$ and ${ }^{13} \mathrm{C}$ NMR spectra were recorded with a Bruker DPX 200 $(200 \mathrm{MHz})$ spectrometer. Tetramethylsilane $\left(\mathrm{SiMe}_{4}\right)$ was used as internal standard $(\delta=0)$.

3,5-dimethoxybenzaldehyde (4). To a round-bottom flash, equipped with a $\mathrm{CaCl}_{2}$ tube, was added dry dichloromethane $(15 \mathrm{~mL})$ and oxalyl chloride $(0.6 \mathrm{~mL}, 6.5 \mathrm{mmol})$. The solution was kept at $-78{ }^{\circ} \mathrm{C}$ and dimethyl sulfoxide $(1 \mathrm{~mL}, 13 \mathrm{mmol})$ in dichloromethane $(1 \mathrm{~mL})$ was added. The reaction mixture was stirred for 2 minutes and 3,5-dimethoxybenzylic alcohol (3) $(1 \mathrm{~g}, 6.0 \mathrm{mmol})$ in dichloromethane was added. After $15 \mathrm{~h}$ triethylamine $(4.2 \mathrm{~mL}, 30 \mathrm{mmol})$ was added. The reaction mixture was stirred at room temperature for 5 hours. After this time water $(40 \mathrm{~mL})$ was added and the mixture was extracted with dichloromethane $(5 \times 20 \mathrm{~mL})$. The organic phase was washed with an aqueous solution of $\mathrm{HCl}(1 \mathrm{M}, 20 \mathrm{~mL}), 5 \%$ aqueous $\mathrm{NaHCO}_{3}(20 \mathrm{~mL})$, brine $(20 \mathrm{~mL})$, dried over $\mathrm{MgSO}_{4}$ 
and concentrated under reduced pressure to yield a yellow oil This oil was purified by flash chromatography (hexane/diethyl ether, 3:1) to provide the required aldehyde (4) which was recrystallized in diethyl ether/hexane (white solid, $868 \mathrm{mg}, 5.23$ mmol, 87.8\%); m.p. $54-55{ }^{\circ} \mathrm{C}$; IR (KBr) $v_{\max }$ : 3525, 3500, $3400,3000,2800,1710,1600,1475,1375,1350,1300,1200$, 1060, 950, 900, 825, $700 \mathrm{~cm}^{-1} ;{ }^{1} \mathrm{H} \mathrm{NMR} \quad\left(\mathrm{CDCl}_{3}, 200 \mathrm{MHz}\right)$ $\delta: 3.80\left(\mathrm{~s}, 2 \times \mathrm{OCH}_{3}\right), 6.70(\mathrm{t}, J=2.4 \mathrm{~Hz}, \mathrm{H}-4), 7.00(\mathrm{~d}, J$ $=2.4 \mathrm{~Hz}, \mathrm{H}-2$ and $\mathrm{H}-6), 9.90(\mathrm{~s}, \mathrm{CHO}) \cdot{ }^{13} \mathrm{C} \mathrm{NMR}\left(\mathrm{CDCl}_{3}\right.$, $50 \mathrm{MHz}) \delta$ : $55.6\left(2 \mathrm{xOCH}_{3}\right), 107.1(\mathrm{C}-2$ and $\mathrm{C}-6), 107.2(\mathrm{C}-$ 4), $138.4(\mathrm{C}-1), 161.3(\mathrm{C}-3$ and $\mathrm{C}-5), 191.9(\mathrm{C}=\mathrm{O})$. MS $\mathrm{m} / \mathrm{z}$ (\%): 167, $\left(\mathrm{C}_{9} \mathrm{H}_{10} \mathrm{O}_{3},[\mathrm{M}+1]^{+}, 100 \%\right), 165$ (70), 137 (9), 135 (35), 95 (20), 63 (20).

1-(3,5-dimethoxyphenyl)pentan-1-ol (5). 1.6 M Butillithyum in hexane $(5.0 \mathrm{~mL}, 8 \mathrm{mmol})$ was added to a stirred solution of 3,5-dimethoxybenzaldehyde (4) in dry THF $(5 \mathrm{~mL})$ at $-78{ }^{\circ} \mathrm{C}$ for 1 hour and at room temperature for 5 hours. Water $(30 \mathrm{~mL})$ was added and the THF was eliminated in rotary evaporator. The aqueous layer was extracted with dichloromethane $(5 \times 20$ $\mathrm{mL}$ ). The combinated organic extract was washed with brine, dried over $\mathrm{MgSO}_{4}$ and concentrated under reduced pressure to provide a yellow oil which was purified by flash chromatography (hexane/diethyl ether, 2:1) to yield the required compound (5) (1.42 g, $6.31 \mathrm{mmol}, 94 \%)$. IR (film) $v_{\max } 3421,3005,2955$, 2934, 1608, 1598, 1465, 1429, 1204, 1154, 1063, $838 \mathrm{~cm}^{-1} .{ }^{1} \mathrm{H}$ NMR $\left(\mathrm{CDCl}_{3}, 200 \mathrm{MHz}\right) \delta: 0.91\left(\mathrm{t}, J=7.0 \mathrm{~Hz}, \mathrm{CH}_{3}\right), 1.25-$ 1.48 (m, H-3' and H-4'), 1.70-1.78 (m, H-2'), 1.87 (s, OH), $3.82\left(\mathrm{~s}, 2 \times \mathrm{OCH}_{3}\right), 4.61(\mathrm{dd}, J=7.3,5.9 \mathrm{~Hz}, \mathrm{H}-1$ '), 6.39 (t, $J=2.3 \mathrm{~Hz}, \mathrm{H}-4), 6.52(\mathrm{~d}, J=2.3 \mathrm{~Hz}, \mathrm{H}-2$ and $\mathrm{H}-6) .{ }^{13} \mathrm{C}$ NMR $\left(\mathrm{CDCl}_{3}, 50 \mathrm{MHz}\right) \delta$ : 13.5 (C-5'), 22.1 (C-4'), 27.5 (C-3'), 38.2 (C-2'), $55.8\left(2 \times \mathrm{OCH}_{3}\right), 74.3(\mathrm{C}-1$ ') $, 98.6(\mathrm{C}-2$ and $\mathrm{C}-6), 98.9$ (C-4), 147.1 (C-1), 160.4 (C-3 and C-5). MS m/z (\%): 224, $\left(\mathrm{C}_{13} \mathrm{H}_{20} \mathrm{O}_{3}, \mathrm{M}^{+}, 12 \%\right), 168$ (100), 139 (47), 124 (21), 96 (12), 65 (11).

1,3-dimethoxy-5-(pent-1-en-1-yl)benzene (8). To a solution of 1-(3,5-dimethoxyphenyl)pentan-1-ol (5) $(215 \mathrm{mg}, 0.9 \mathrm{mmol})$ in dry benzene $(6 \mathrm{~mL})$ in a round-bottom flash, was added $p$ toluenesulfonic acid $(10 \mathrm{mg})$. The reaction mixture was refluxed for 4 hours before addition ethyl acetate $(10 \mathrm{~mL})$ and extraction with water $(3 \times 10 \mathrm{~mL})$. The organic phase was washed with brine $(20 \mathrm{~mL})$, dried over $\mathrm{MgSO}_{4}$ and concentrated in rotary evaporator. The mixture was purified by flash chromatography (hexane/diethyl ether, 40:1) to produce the required alkene (8) (yellow oil, $99 \mathrm{mg}, 0.49 \mathrm{mmol}, 54 \%$ ) and the dimer (7) (white solid, $28 \mathrm{mg}, 0.14 \mathrm{mmol}, 14.7 \%$ ). Data for (7): m.p. 138.2$139.0{ }^{\circ} \mathrm{C}$. IR $(\mathrm{KBr}) v_{\max } 2989,2946,2866,2833,1614,1577$, $1485,1452,1420,1340,1320,1283,1270,1223,1183,1099$, $1052,986,947,850,804 \mathrm{~cm}^{-1} .{ }^{1} \mathrm{H}$ NMR $\left(\mathrm{CDCl}_{3}, 200 \mathrm{MHz}\right)$ $\delta$ : $0.48-0.56(\mathrm{~m}, 4 \mathrm{H}, \mathrm{H}-2$ ' and $\mathrm{H}-2$ '' $), 0.64(\mathrm{t}, 6 \mathrm{H}, J=7.3 \mathrm{~Hz}$, $\mathrm{H}-4$ ' and $\mathrm{H}-4{ }^{\prime \prime}$ ), 0.98 (sextet, $4 \mathrm{H}, \mathrm{H}-3$ ' and $\mathrm{H}-3$ ''), $1.62-$ $1.70\left(\mathrm{~m}, 2 \mathrm{H}, \mathrm{H}_{\mathrm{A}}-1\right.$ 'and $\mathrm{H}_{\mathrm{A}}-1$ ', $), 2.02-2.04\left(\mathrm{~m}, 2 \mathrm{H}, \mathrm{H}_{\mathrm{B}}-1\right.$ ' and $\left.\mathrm{H}_{\mathrm{B}}-1, ’\right), 3.84$ and $3.86\left(2 \mathrm{~s}, 12 \mathrm{H}, 4 \mathrm{x} \mathrm{OCH}_{3}\right), 4.35(\mathrm{t}, 2 \mathrm{H}, J=$ $3.8 \mathrm{~Hz}, \mathrm{H}-9$ and $\mathrm{H}-10), 6.36(\mathrm{~d}, 2 \mathrm{H}, J=2.4 \mathrm{~Hz}, \mathrm{H}-2$ and $\mathrm{H}-6), \quad 6.46(\mathrm{~d}, 2 \mathrm{H}, \quad J=2.4 \mathrm{~Hz}, \mathrm{H}-4$ and $\mathrm{H}-8) .{ }^{13} \mathrm{C}$ NMR $\left(\mathrm{CDCl}_{3}, 50 \mathrm{MHz}\right) \delta: 13.9$ (C-4' and $\left.\mathrm{C} 4{ }^{\prime \prime}\right), 22.8$ (C-3' and $\mathrm{C}$ 3') 25.7 (C-2' and C-2''), 37.4 (C-9 and C-10), 38.3 (C-1' and $\left.\mathrm{C}-1{ }^{\prime \prime}\right), 55.2$ and $55.19\left(4 \mathrm{xOCH}_{3}\right), 96.3(\mathrm{C}-2$ and $\mathrm{C}-6)$, 103.2 (C-4 and C-8), 119.3 (C-9a and C-10a), 140.6 (C-4a and $\mathrm{C}-8 \mathrm{a}), 157.2$ (C-3 and C-7), 158.3 (C-1 and C-5). MS $m / z(\%): 355\left(\left[\mathrm{M}^{+}-\mathrm{C}_{4} \mathrm{H}_{9}\right], 78\right) ; 298(100), 283(31), 255(8)$, 240 (6), 149 (5). $\mathrm{C}_{26} \mathrm{H}_{36} \mathrm{O}_{4}$ calcd. $\mathrm{C} 75.7 \%, \mathrm{H} 8.8 \%$; found $\mathrm{C}$ $75.8 \%, H, 8.7 \%$. Data for (8): IR (film) $v_{\max } 2998,2956$, 2928, 2837, 1592, 1458, 1424, 1344, 1292, 1204, 1152, 1065 , $964,845,827 \mathrm{~cm}^{-1} .{ }^{1} \mathrm{H}$ NMR $\left(\mathrm{CDCl}_{3}, 200 \mathrm{MHz}\right) \delta: 0.93(\mathrm{t}$, $\left.J=7.2, \mathrm{CH}_{3}\right), 1.40-1.58\left(\mathrm{~m}, \mathrm{H}-4^{\prime}\right), 2.19(\mathrm{dt}, J=7.9,4.9 \mathrm{~Hz}$ H-3'), $3.79\left(\mathrm{~s}, 2 \mathrm{xOCH}_{3}\right), 6.18(\mathrm{dt}, J=15.8,5.6 \mathrm{~Hz}, \mathrm{H}-2$ '), $6.32\left(\mathrm{~d}, J=15.8 \mathrm{~Hz}, \mathrm{H}-1^{\prime}\right), 6.34(\mathrm{t}, J=2.3 \mathrm{~Hz}, \mathrm{H}-2), 6.51$ (d, $J=2.3 \mathrm{~Hz}, \mathrm{H}-4$ and $\mathrm{H}-6) .{ }^{13} \mathrm{C}$ NMR $\left(\mathrm{CDCl}_{3}, 50 \mathrm{MHz}\right)$

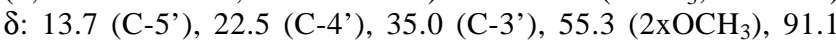

(C-2), 104.0 (C-4 and C-6), 129.84 (C-2'), 131.5 (C-1'), 140.0 (C-5), 160.9 (C-1 and C-3). MS m/z (\%): 206, $\mathrm{C}_{13} \mathrm{H}_{18} \mathrm{O}_{2}, \mathrm{M}^{+}$ (100), 191 (45), 177 (65), 151 (22), 91 (20), 77 (12). $\mathrm{C}_{13} \mathrm{H}_{18} \mathrm{O}_{2}$ calcd. C $75.7 \%, \mathrm{H} 8.8 \%$; found $\mathrm{C} 75.7 \%, \mathrm{H} 8.9 \%$.

The dehydration of (5) was also carried out with $\mathrm{HCl}$ in acetone and with thionyl chloride in pyridine. In both cases the compound isolated was 5-(1-chloropent-1-yl)-1,3-dimethoxybenzene (6) in $30 \%$ yield, as a yellow oil. IR (film) $v_{\max } 3001$, 2964, 2876, 2842, 1608, 1464, 1438, 1356, 1290, 1206, 1168, $1064,927,844,740 \mathrm{~cm}^{-1} .{ }^{1} \mathrm{H}$ NMR $\left(\mathrm{CDCl}_{3}, 200 \mathrm{MHz}\right) \delta: 0.90$ $\left(\mathrm{t}, J=7.2 \mathrm{~Hz}, \mathrm{CH}_{3}\right), 1.25-1.37$ (m, H-3' and H-4'), 2.02-2.10 (m, H-2'), $3.79\left(\mathrm{~s}, 2 \mathrm{xOCH}_{3}\right), 4.75(\mathrm{dd}, J=7.0,6.6 \mathrm{~Hz}, \mathrm{H}-$ $\left.1^{\prime}\right), 6.39(\mathrm{t}, \quad J=2.3 \mathrm{~Hz}, \mathrm{H}-2), 6.52(\mathrm{~d}, J=2.3 \mathrm{~Hz}, \mathrm{H}-4$ and H-6). ${ }^{13} \mathrm{C}$ NMR $\left(\mathrm{CDCl}_{3}, 50 \mathrm{MHz}\right) \delta: 13.4(\mathrm{C}-5$ ' $), 21.7\left(\mathrm{C}-4^{\prime}\right)$, 28.7 (C-3'), $39.2\left(\mathrm{C}-2^{\prime}\right), 54.9\left(2 \mathrm{xOCH}_{3}\right), 63.4(\mathrm{C}-1$ ' $), 104.6$ (C-4 and C-6), 99.5 (C-2), 143.8 (C-5), 160.4 (C-1 and C3). MS m/z (\%): $206[\mathrm{M}-\mathrm{HCl}]^{+.}(63), 191$ (41), 177 (42), 151 (23), 91 (25), 77 (22).

1,3-dimethoxy-5-(pent-1-yl)benzene (9). A solution of 1,3dimethoxy-5-(pent-1-en-1-yl)benzene (8) (300 mg, $1.46 \mathrm{mmol}$ ) in ethyl acetate $(10 \mathrm{~mL})$, was placed in a $50 \mathrm{~mL}$ round bottle flask containing $10 \% \mathrm{Pd}-\mathrm{C}$ ( $44 \mathrm{mg}, 4.1 \mathrm{mmol})$, and kept under hydrogen atmosphere $\left(1.0 \times 10^{5} \mathrm{~Pa}\right)$ and $40{ }^{\circ} \mathrm{C}$ for 2 hours. After this period of time the catalyst was filtered off through a Celite pad, dried over $\mathrm{MgSO}_{4}$ and the solvent evaporated under reduced pressure to yield the required compound (9) (303 mg, $1.46 \mathrm{mmol}, 100 \%$ ) as a clear oil. IR (film) $v_{\max } 2998,2955$, 2930, 2857, 1595,1463, 1428, 1350, 1323, 1292, 1205, 1150, $1060,925,828 \mathrm{~cm}^{-1} .{ }^{1} \mathrm{H}$ NMR $\left(\mathrm{CDCl}_{3}, 50 \mathrm{MHz}\right) \delta: 0.89(\mathrm{t}$, $\left.J=6.6 \mathrm{~Hz} ; \mathrm{CH}_{3}\right), 1.25-1.35\left(\mathrm{~m}, \mathrm{H}-3{ }^{\prime}\right.$ and $\left.\mathrm{H}-4{ }^{\prime}\right), 1.53-1.64$ (m, H-2'), 2.54 (dd, $\left.J=7.7,7.6 \mathrm{~Hz}, \mathrm{H}-1^{\prime}\right), 3.80\left(\mathrm{~s}, 2 \mathrm{xOCH}_{3}\right)$, $6.29(\mathrm{t}, J=2.3 \mathrm{~Hz}, \mathrm{H}-2), 6.30(\mathrm{~d}, J=2.3 \mathrm{~Hz}, \mathrm{H}-4$ and $\mathrm{H}-6)$. ${ }^{13} \mathrm{C}$ NMR $\left(\mathrm{CDCl}_{3}, 50 \mathrm{MHz}\right) \delta: 14.0$ (C-5'), $22.6 \quad\left(\mathrm{C}-4^{\prime}\right)$, 31.0 (C-2'), 31.5 (C-3'), 36.3 (C-1'), $55.2\left(2 \mathrm{xOCH}_{3}\right), 97.5$ (C-2), 106.5 (C-6 and C-4), 145.4 (C-5), 160.7 (C-1 and C-3). MS m/z (\%): $209[\mathrm{M}+1]^{+}(15), 208\left(\mathrm{C}_{13} \mathrm{H}_{20} \mathrm{O}_{2}, \mathrm{M}^{+}\right.$ $16 \%), 152$ (100), 121 (5), 91 (8), 77 (8). $\mathrm{C}_{13} \mathrm{H}_{20} \mathrm{O}_{2}$ calcd. $\mathrm{C}$ $75.0 \%, \mathrm{H} 9.7 \%$; found $\mathrm{C} 74.9 \%$, $\mathrm{H} 9.6 \%$.

2-methoxy-6-(pent-1-yl)-1,4-benzoquinone (10). To a solution of 1,3-dimethoxy-5-(pent-1-yl)benzene (9) $(60 \mathrm{mg}$, $0.29 \mathrm{mmol})$ was added $\mathrm{CrO}_{3}(60 \mathrm{mg}, 0.58 \mathrm{mmol})$ in acetic acid at room temperature and stirring for 30 hours. After this time, was added water $(15 \mathrm{~mL})$ and the mixture was extracted with dichloromethane $(3 \times 20 \mathrm{~mL})$. The combined organic phase was washed with brine $(10 \mathrm{~mL})$, dried over $\mathrm{MgSO}_{4}$ and concentrated on rotary evaporator. The resultant oil was submitted to flash chromatography (hexane/ethyl ether, 4:1) to yield the quinone (10) which was recrystallized in dichloromethane/hexane (yellow solid, $42 \mathrm{mg}, 0.2 \mathrm{mmol}, 70 \%$ ), m.p. $70.2-71.0{ }^{\circ} \mathrm{C}$. IR $(\mathrm{KBr}) v_{\max } 3074,2921,2852,1680$, $1654,1630,1601,1472,1446,1426,1367,1351,1326,1240$, $1178,1062,1029,901,855,797,719 \mathrm{~cm}^{-1} .{ }^{1} \mathrm{H} \mathrm{NMR}\left(\mathrm{CDCl}_{3}\right.$, $200 \mathrm{MHz}) \delta: 0.91\left(\mathrm{t}, J=6.5 \mathrm{~Hz}, \mathrm{CH}_{3}\right), 1.15-1.58(\mathrm{~m}, \mathrm{H}-4$ ', H-3' and H-2'), 2.39 (dt, $\left.J=7.5,1.4 \mathrm{~Hz}, \mathrm{H}-1^{\prime}\right), 3.79$ (s, $\left.\mathrm{OCH}_{3}\right), 5.87(\mathrm{~d}, J=2.4 \mathrm{~Hz}, \mathrm{H}-3), 6.48(\mathrm{dt}, J=2.4,1.4 \mathrm{~Hz}$, $\mathrm{H}-5) .{ }^{13} \mathrm{C} \mathrm{NMR}\left(\mathrm{CDCl}_{3}, 50 \mathrm{MHz}\right) \delta: 13.9(\mathrm{C}-5$ ' $), 22.4\left(\mathrm{C}-2^{\prime}\right)$, 27.4 (C-4'), 28.7 (C-1'), $31.4\left(\mathrm{C}-3\right.$ ') $, 56.3\left(\mathrm{OCH}_{3}\right), 107.1$ (C3), 132.9 (C-5), 147.6 (C-2), 158.9 (C-6), 182.1 (C-4), 187.7 $(\mathrm{C}-1)$. MS m/z (\%): 209, $\mathrm{C}_{12} \mathrm{H}_{16} \mathrm{O}_{3},[\mathrm{M}+1]^{+}(100), 208$ (36), 179 (20), 153 (70), $124(20) . \mathrm{C}_{12} \mathrm{H}_{16} \mathrm{O}_{3}$ calcd. C 69.2\%, H $7.7 \%$; found $\mathrm{C} 69.2 \%, \mathrm{H} 7.8 \%$.

1,2,4-triacetoxi-5-methoxy-3-(pent-1-yl)benzene (11). A stirred solution of 2-methoxy-6-(pent-1-yl)-1,4-benzoquinone (10) (113 $\mathrm{mg}, 0.54 \mathrm{mmol})$, acetic anhydride $(2 \mathrm{~mL})$ and conc. $\mathrm{H}_{2} \mathrm{SO}_{4}(0.3$ $\mathrm{mL}$ ) was placed in a round-bottomed flask at room temperature. After 22 hours the mixture was cooled and $20 \mathrm{~mL}$ of water was added. The aqueous phase was extracted with ethyl ether $(5 \mathrm{x}$ $20 \mathrm{~mL}$ ). The combined organic phase was washed with brine, dried over $\mathrm{MgSO}_{4}$ and concentrated on rotary evaporator to 
leave a white solid which was recrystallised in ethyl ether/hexane and identified as compound (11) (146 mg, $0.41 \mathrm{mmol}, 77 \%)$, m.p. 92.9-94.0 ${ }^{\circ} \mathrm{C}$. IR (KBr) $v_{\max } 2953,1768,1487,1372$, $1213,1187,1118,1055,1016,927,889 \mathrm{~cm}^{-1} .{ }^{1} \mathrm{H}$ NMR $\left(\mathrm{CDCl}_{3}, 200 \mathrm{MHz}\right) \delta: 0.84\left(\mathrm{t}, J=6.6 \mathrm{~Hz}, \mathrm{CH}_{3}\right), 1.25-1.50(\mathrm{~m}$, H-4', H-3' and H-2'), $2.26\left(\mathrm{~s}, 1-\mathrm{CH}_{3}\right), 2.29\left(\mathrm{~s}, 2-\mathrm{CH}_{3}\right), 2.32$ $\left(\mathrm{s}, 4-\mathrm{CH}_{3}\right), 2.41\left(\mathrm{dd}, \quad J=7.7,7.5 \mathrm{~Hz}, \mathrm{H}-1^{\prime}\right), 3.78(\mathrm{~s}$, $\left.\mathrm{OCH}_{3}\right), 6.70(\mathrm{~s}, \mathrm{H}-6) .{ }^{13} \mathrm{C} \mathrm{NMR}\left(\mathrm{CDCl}_{3}, 50 \mathrm{MHz}\right) \delta: 13.9(\mathrm{C}-$ 5'), $20.3\left(1-\mathrm{CH}_{3}\right), 20.4\left(2-\mathrm{CH}_{3}\right), 20.7\left(4-\mathrm{CH}_{3}\right), 22.2\left(\mathrm{C}-1^{\prime}\right)$, 25.3 (C-4'), 28.6 (C-2'), 31.8 (C-3'), $56.2\left(\mathrm{OCH}_{3}\right), 125.9$ (C6), 130.2 (C-3), 133.9 (C-2), 136.0 (C-1), 140.2 (C-4), 149.2 (C-5), $168.1 \quad(1-\mathrm{C}=\mathrm{O}), 168.3(2-\mathrm{C}=\mathrm{O}), 168.4(4-\mathrm{C}=\mathrm{O})$.

2-acetoxy-5-methoxy-3-(pent-1-yl)-1,4-benzoquinone (12). To a round-bottom flask $(25 \mathrm{~mL})$, was added THF $(4 \mathrm{~mL}), \mathrm{LiAlH}_{4}$ (30 mg, $0.80 \mathrm{mmol}$ ) and 1,2,4-triacetoxy-5-methoxy-3-(pent-1yl)benzene (11) $(127 \mathrm{mg}, 0.36 \mathrm{mmol})$. The reaction mixture was refluxed for 12 hours and after this time water $(10 \mathrm{~mL})$ was added and the THF evaporated. The mixture was extracted with dichloromethane $(5 \times 20 \mathrm{~mL})$ and the combined organic phase washed with brine $(10 \mathrm{~mL})$, dried over $\mathrm{MgSO}_{4}$ and concentrated under reduced pressure to a yellow solid. This solid was dissolved in benzene $(3 \mathrm{~mL})$ and a $1 \%$ aqueous solution of $\mathrm{FeCl}_{3}(1 \mathrm{~mL})$ was added. This reaction mixture was maintained at room temperature for 3 hours before the extraction of the product with ethyl acetate $(4 \times 10 \mathrm{~mL})$. The organic phase was washed with brine dried over $\mathrm{MgSO}_{4}$ and, concentrated under reduced pressure to produce an orange oil. This oil was purified by silicagel flash column chromatography with hexane/diethyl ether $(2: 1)$ to provide the required quinone (12) (43 mg, $0.76 \mathrm{mmol}, 47 \%$ ), as orange solid. m.p. 128.3$129.1{ }^{\circ} \mathrm{C}$. IR $(\mathrm{KBr}) v_{\max } 3064,2951,2929,2861,1764,1683$, $1654,1587,1466,1264,1231,1187,1160,1039,915,862$ $\mathrm{cm}^{-1} .{ }^{1} \mathrm{H}$ NMR $\left(\mathrm{CDCl}_{3}, 200 \mathrm{MHz}\right) \delta: 0.87(\mathrm{t}, J=6.6 \mathrm{~Hz}$, $\mathrm{CH}_{3}$ ), 1.25-1.52 (m, H-4', H-3' and $\mathrm{H}^{\prime}{ }^{\prime}$ ), 1.69 (s, 2- $\mathrm{CH}_{3}$ ), $2.34\left(\mathrm{dd}, J=7.5 \mathrm{~Hz}, \mathrm{H}-1\right.$ ') $3.85\left(\mathrm{~s}, \mathrm{OCH}_{3}\right), 5.72(\mathrm{~s}, \mathrm{H}-6)$. ${ }^{13} \mathrm{C}$ NMR $\left(\mathrm{CDCl}_{3}, 50 \mathrm{MHz}\right) \delta: 13.9\left(\mathrm{C}-5^{\prime}\right), 20.2\left(2-\mathrm{CH}_{3}\right)$, 22.3 (C-1'), 23.9 (C-4'), 27.8 (C-2'), 31.6 (C-3'), 57.1 $\left(\mathrm{OCH}_{3}\right), 101.1(\mathrm{C}-6), 133.1(\mathrm{C}-3), 151$ (C-2), 164.1 (2-CO), 167.7 (C-5), 178.1 (C-4), 178.4 (C-1). MS m/z (\%): 267, $\mathrm{C}_{14} \mathrm{H}_{19} \mathrm{O}_{5},[\mathrm{M}+1]^{+} \cdot(5), 225(100), 168$ (37), 139 (8). $\mathrm{C}_{14} \mathrm{H}_{18} \mathrm{O}_{5}$ calcd. C $63.2 \%, \mathrm{H} 6.8 \%$; found $\mathrm{C} 63.1 \%, \mathrm{H}, 6.7 \%$.

\section{Extraction, purification and hydrogenation of sorgoleone (1).}

Crude sorgoleone (1) was extracted from Sorghum bicolor (L.) Moench (Poaceae) roots using the procedure described in the literature. ${ }^{7}$ The sorgoleone was purified by flash chromatography on silica gel using diethyl ether/hexane $(98: 2)$ as elutant, and the IR, MS and NMR data were the same as those reported in the literature. ${ }^{9}$

The hydrogenation reaction, sorgoleone $(0.3 \mathrm{~g}, 0.84 \mathrm{mmol})$ was placed in a $25 \mathrm{~mL}$ round bottomed flask, along with ethyl acetate $(5 \mathrm{~mL})$ and $10 \% \mathrm{Pd} / \mathrm{C}(23 \mathrm{mg})$, under hydrogen atmosphere $\left(1.0 \times 10^{-5} \mathrm{~Pa}\right)$. The reaction mixture was stirred at $40{ }^{\circ} \mathrm{C}$ for 2 hours, when the catalyst was filtered off through a Celite pad and the solvent evaporated under reduced pressure to yield a yellow solid. This solid was dissolved in benzene ( $3 \mathrm{~mL}$ ) in a $10 \mathrm{~mL}$ round bottomed flask and to this solution a $1 \%$ aqueous $\mathrm{FeCl}_{3}$ solution $(1 \mathrm{~mL})$ was added. The reaction mixture was stirred at room temperature for 3 hours. After this time the product was extracted with ethyl acetate $(4 \times 10 \mathrm{~mL})$. The combined organic extract was washed with brine $(10 \mathrm{~mL})$, dried over $\mathrm{MgSO}_{4}$ and concentrated under reduced pressure to produce the hydrogenated sorgoleone $(13)(306 \mathrm{mg}, 0.88 \mathrm{mmol})$ as a yellow solid in quantitative yield. m.p. 89.3-90.7 ${ }^{\circ} \mathrm{C}$. IR $(\mathrm{KBr}) v_{\max } 3335,2920,1636,1598,1385,1209 \mathrm{~cm}^{-1} .{ }^{1} \mathrm{H}$ NMR $\left(\mathrm{CDCl}_{3}, 200 \mathrm{MHz}\right) \delta: 0.87\left(\mathrm{t}, J=6.4 \mathrm{~Hz}, \mathrm{CH}_{3}\right), 1.07-$ $1.58\left(\mathrm{~m}, 2^{\prime}-\mathrm{CH}_{2}\right.$ to $\left.14^{\prime}-\mathrm{CH}_{2}\right), 2.43\left(\mathrm{dd}, \quad J=7.4 \mathrm{~Hz}, \mathrm{H}-1^{\prime}\right)$, $3.85\left(\mathrm{~s}, \mathrm{OCH}_{3}\right), 5.83(\mathrm{~s}, \mathrm{H}-6), 7.24(\mathrm{~s}, \mathrm{OH}),{ }^{13} \mathrm{C} \mathrm{NMR}$
$\left(\mathrm{CDCl}_{3}, 50 \mathrm{MHz}\right) \delta: 182.8$ (C-1), 181.7 (C-4), 161.2 (C-5), $151.5(\mathrm{C}-2), 119.3(\mathrm{C}-3), 102.2(\mathrm{C}-6), 56.7\left(\mathrm{OCH}_{3}\right), 31.9-$ 22.6 (C1'-C14'), 14.1 (C-15').

\section{Bioassays}

The experiments were carried out in a greenhouse with Cucumis sativus, Lactuca sativa, Desmodium tortuosum, Hyptis suaveolens and Euphorbia heterophylla. For the bioassays a stock solution was prepared dissolving $50 \mathrm{mg}$ each tested compound $(\mathbf{1}, \mathbf{1 2}$ and $\mathbf{1 3})$ in dimethylsulfoxide $(0.1 \mathrm{~mL})$ and water $(100 \mathrm{~mL})$. A solution with the same composition described above, but without the compound to be tested, was used as a control. To each plastic pot of $0.10 \mathrm{dm}^{3}$, was added washed sand saturated with the solution of the test compound $(18 \mathrm{~mL} / 160 \mathrm{~g}$ of sand, corresponding to $5.6 \mathrm{mg}$ at a.i./g substrate) was added. Ten seeds of each test plant were placed in each pot. The pots were kept in a greenhouse at $25{ }^{\circ} \mathrm{C}$, watered regularly to maintain the humidity at $13.3 \% \mathrm{w} / \mathrm{w}$, and three times a week, a solution containing the required nutrients was applied. After 14 days of sowing the plants were harvested, the roots and aerial parts separated and weighed. They were then dried at $75{ }^{\circ} \mathrm{C}$, to constant weight and the mass of the dried matter determined.

All treatments were replicated six times in a completely randomized design. The percentage of root and aerial part growth inhibition was calculated in relation to the mass of the control, respectively. The data were analysed using Tukey's test at 0.05 probability level.

\section{RESULTS AND DISCUSSION}

The commercially available 3,5-dimethoxybenzylic alcohol (3) was converted into the corresponding aldehyde (4), in $88 \%$ yield via a Swern oxidation. ${ }^{15}$

In order to obtain a short chain analogue of sorgoleone, the aldehyde (4) was treated with $\mathrm{BuLi}$ and the corresponding alcohol (5) was isolated in $94 \%$ yield. We considered to convert the alcohol (5) into the corresponding deoxy-compound (9) via a dehydration procedure to produce $(\mathbf{8})$, followed by catalytic hydrogenation.

Initially the alcohol (5) was reacted with $\mathrm{HCl}$ in acetone, but the chlorocompound (6) was the only product isolated in $30 \%$. The use of $\mathrm{SOCl}_{2}$ in pyridine also allowed the isolation of compound 6 in $32 \%$. A further attempt involving the use of $\mathrm{BF}_{3} \cdot \mathrm{Et}_{2} \mathrm{O}$ as a dehydrating agent ${ }^{16}$ was carried out and the only product isolated was the solid 7 (Scheme 1).

The structure of this compound (7) was deduced by spectroscopic means. The infrared spectra showed absorptions at 1614 and $1577 \mathrm{~cm}^{-1}$ due to $\mathrm{C}=\mathrm{C}$ stretching. The molecular formula was established as $\mathrm{C}_{26} \mathrm{H}_{36} \mathrm{O}_{4}$ by ${ }^{13} \mathrm{C}$ NMR and $\mathrm{CHN}$ analysis. In the mass spectrum the molecular ion peak was not observed and peaks at $\mathrm{m} / \mathrm{z} 355$ and 298 were found, corresponding to the fragments resulting from the loss of the alkyl chains.

The ${ }^{13} \mathrm{C}$ NMR spectrum gave rise to 13 carbon signals: four non-hydrogenated carbons, two aromatic methines, one benzilic $\mathrm{CH}$, three $\mathrm{CH}_{2}$ and three $\mathrm{CH}_{3}$, identified via DEPT. All the signals were assigned via a HMQC spectrum.

The ${ }^{1} \mathrm{H}$ NMR spectrum showed a pair of doublets at $\delta 6.46$ $(J=2.4 \mathrm{~Hz})$ and $\delta 6.36(J=2.4 \mathrm{~Hz})$ for the 4 aromatic hydrogens. The absorptions of the four methoxy groups appeared as singlets at $\delta 3.84$ and $\delta 3.88$. The hydrogens $\mathrm{H}-9$ and $\mathrm{H}-10$ gave a triplet $(J=3.8 \mathrm{~Hz})$ at $\delta 4.32$. The two $\mathrm{CH}_{3}$ groups from the aliphatic chains were equivalents and appeared as a triplet at $\delta 0.64(J=7.3 \mathrm{~Hz})$. The triplet at $\delta 0.64$ was assigned to the 4' $-\mathrm{CH}_{3}$ and 4' $-\mathrm{CH}_{3}$. From the COSY spectrum the sextet at $\delta 0.98$ and the multiplet centred at $\delta 0.52$ were assigned to 3' $-\mathrm{CH}_{2} / 3$ ' ' $-\mathrm{CH}_{2}$ and 2' $-\mathrm{CH}_{2} / 2$ ' ' $-\mathrm{CH}_{2}$, respectively. 
The methylene groups 1'- $\mathrm{CH}_{2}$ and 1' $-\mathrm{CH}_{2}$ are close to a quiral centre (C-9 and C-10), so hydrogens $\mathrm{H}_{\mathrm{A}}$ and $\mathrm{H}_{\mathrm{B}}$ are not chemically equivalent and gave rise to resonances with different chemical shifts (multiplets centred at $\delta 1.66$ and 2.01). All the assignments were confirmed by COSY.

The formation of this dimer involves two consecutive Friedal-Crafts alkylation reactions.

Successful dehydration of the alcohol (5) was accomplished using $p$-toluenesulphonic acid in dry benzene ${ }^{17}$ to produce the required alkene $(\mathbf{8})$ in $54 \%$ yield, along with $14.7 \%$ of the dimer (7) (Scheme 1).

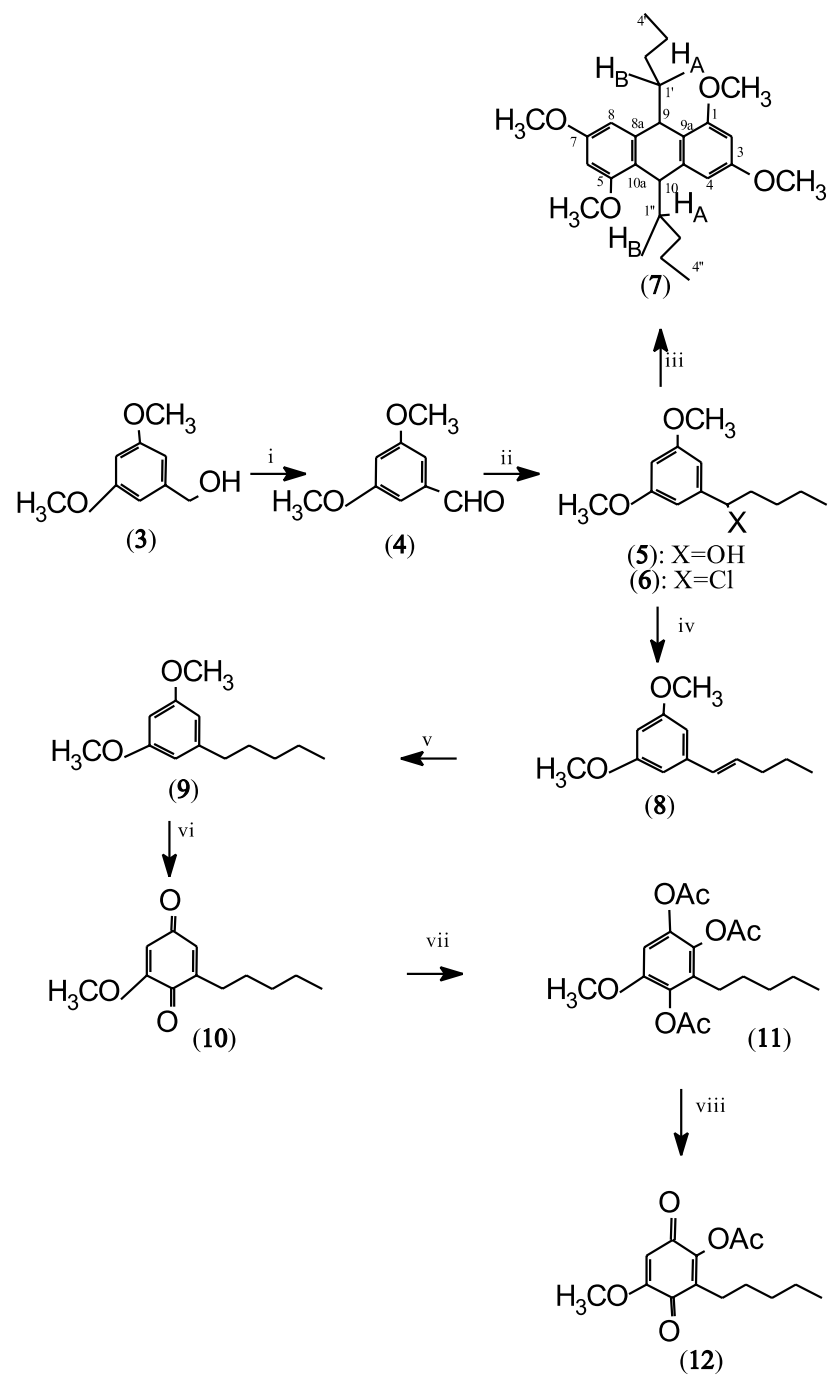

Scheme 1. Reagents and conditions: (i) $(\mathrm{CClO})_{2}$, dichloromethane, 30 min., $30{ }^{\circ} \mathrm{C}$; DMSO, $-78{ }^{\circ} \mathrm{C}, 1.5 \mathrm{~h}$; Triethylamine, $25{ }^{\circ} \mathrm{C}, 5 \mathrm{~h}$, 87.8\%; (ii) BuLi, $-78{ }^{\circ} \mathrm{C}, \quad 1 \mathrm{~h} ; \quad 25{ }^{\circ} \mathrm{C}, \quad 5 h, 94 \%$ of (5); (iii) $\mathrm{BF}_{3} \cdot \mathrm{Et}_{2} \mathrm{O} /$ dichloromethane, $25{ }^{\circ} \mathrm{C}, 2.5 \mathrm{~h}$; (iv) p-toluenesulphonic acid, benzene, reflux, 4h, 54\%; (v) $\mathrm{H}_{2}$, AcOEt, $10 \% \mathrm{Pd}-\mathrm{C}, 40$ ${ }^{\circ} \mathrm{C}, 2 \mathrm{~h}, 100 \%$; (vi) $\mathrm{CrO}_{3} / \mathrm{HOAc}, 25{ }^{\circ} \mathrm{C}, 30 \mathrm{~h}, 70 \%$; (vii) $\mathrm{Ac}_{2} \mathrm{O} /$ $\mathrm{H}_{2} \mathrm{SO}_{4}, 25{ }^{\circ} \mathrm{C}, 22 \mathrm{~h}, 77 \%$; (viii) $\mathrm{LiAlH}_{4}, \mathrm{THF}$, reflux, $12 \mathrm{~h} ; \mathrm{FeCl}_{3}$, benzene, $3 h, R T, 47 \%$.

This alkene (8), was then submitted to a catalytic hydrogenation under $1 \mathrm{~atm}$ of hydrogen ${ }^{18}$. The reaction did not occur at $30{ }^{\circ} \mathrm{C}$, but at $40{ }^{\circ} \mathrm{C}$ the required product (9) was isolated in $100 \%$ yield.

At this stage the dimethoxy compound (9) was submitted to an oxidation with $\mathrm{CrO}_{3}$ in acetic acid ${ }^{19}$, to afford $70 \%$ of quinone (10) as a crystalline yellow solid. The infrared spectrum at this compound showed strongs absorptions at $1680 \mathrm{~cm}^{-1}$ and $1650 \mathrm{~cm}^{-1}$ due to the $\mathrm{C}=\mathrm{O}$ and $\mathrm{C}=\mathrm{C}$ stretching respectively.
The ${ }^{1} \mathrm{H}$ NMR spectrum exhibited a doublet at $\delta 5.87(J=2.4$ $\mathrm{Hz})$ due to $\mathrm{H}-3$ and a double triplet at $\delta 6.48(J=2.4$ and 1.4 $\mathrm{Hz}$ ) due to $\mathrm{H}-5$. Special features in the ${ }^{13} \mathrm{C}$ NMR spectrum on the absorptions at $\delta 187.7$ and $\delta 182.1$ due to the carbonylic groups.

The oxidation of carbon C-3 was accomplished by the Thielle acetoxylation, as described by MacLamore $(1951)^{19}$. The procedure consisted in dissolving the quinone (10) in acetic anhydride, followed by addition of sulfuric acid. This allowed the obtention of the triacetate $\mathbf{1 1}$ in $94 \%$. The infrared of this compound showed a strong absorption at $1768 \mathrm{~cm}^{-1}(\mathrm{C}=\mathrm{O}$ ester) and in the ${ }^{13} \mathrm{C}$ NMR spectrum were observed three singlets at $\delta 168.1,168.3$ and 168.4 due to the acetate groups.

In order to remove the acetate groups compound (11) was treated with $\mathrm{LiAlH}_{4}{ }^{20}$. After complete consumption of the starting material the crude product was oxidized with $\mathrm{FeCl}_{3}$, and purification allowed the isolation of the acetoxyquinone (12) in $47 \%$ yield. Despite the use of a large excess of $\mathrm{LiAlH}_{4}$ and under reflux condition for several hours, the acetate group at carbon $\mathrm{C}-3$ could not be removed.

Although the acetate group was not removed the methodology developed allowed the preparation of a simple quinone structurally similar to sorgoleone.

In order to evaluate if the triene unit side chain is essential for the herbicidal activity, sorgoleone was quantitatively converted, in two step, into the saturated analogue (13) (Scheme 2).<smiles>C=CC/C=C/C/C=C/CCCCCCCC1=C(O)C(=O)C=C(OC)C1=O</smiles>

(1)

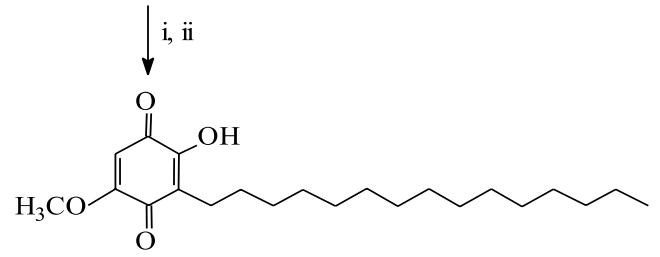

(13)

Scheme 2. Reagents and conditions: (i) $\mathrm{H}_{2}, 1.0 \times 10^{5} \mathrm{~Pa}, 10 \%$ $\mathrm{Pd} / \mathrm{C}, 40{ }^{\circ} \mathrm{C}, 3 \mathrm{~h}$; (ii) $\mathrm{FeCl}_{3} 1 \%, \mathrm{RT}, 8 \mathrm{~h}, 100 \%$.

\section{Bioassays}

The effect of compounds (1), (12) and (13), at $5.6 \mu \mathrm{g} \mathrm{g}^{-1}$ on the development of C. sativus, L. sativa and the commonly occurring field weeds D. tortuosum, E. heterophylla and $H$. suaveolens was evaluated and the results are shown on Table 1.

Only compound (13) caused a small inhibition (2.63\%) on the aerial parts of $C$. sativus. All three compounds inhibited (35.14 to $48.95 \%$ ) the root growth of $C$. sativus.

The growth of L. sativa was also inhibited by all three quinones. The roots were more affected than the aerial parts, and were inhibited by 30.83 to $38.86 \%$.

The effect of the quinones on the broad leaf weed $D$. tortuosum was very small, with the hydrogenated sorgoleone (13) causing $12.99 \%$ inhibition on the aerial part and the synthetic quinone (12) inhibiting the roots by $10.87 \%$.

The aerial parts of E. heterophylla were inhibited by 18.81 to $29.31 \%$. There was no statistical difference among the treatments in this case.

The major effect was observed in the case of $H$. suaveolens, with the quinones causing 48.93 to $69.19 \%$ inhibition on the root growth. The aerial parts in this case were not significantly affected (0.46 to $7.67 \%$ inhibition). In the case of $C$. sativus, 
Table 1. Effect of quinones (1), (12) and (13) at $5.6 \mathrm{mg} \mathrm{g}^{-1}$, on the development of five plant species, after 14 days at $25{ }^{\circ} \mathrm{C}$.

\begin{tabular}{|c|c|c|c|c|}
\hline Treatment (Products) & $\begin{array}{c}\text { Aerial Part } \\
(\mathrm{mg})^{*}\end{array}$ & $\begin{array}{c}\text { Aerial Part } \\
(\% \text { Inhibition }) \\
\end{array}$ & $\begin{array}{l}\text { Roots } \\
(\mathrm{mg})^{*}\end{array}$ & $\begin{array}{c}\text { Roots } \\
\text { (\% Inhibition) } \\
\end{array}$ \\
\hline \multicolumn{5}{|c|}{ C. sativus } \\
\hline Control & $31.5 \mathrm{a}$ & - & $12.1 \mathrm{a}$ & - \\
\hline 1 & $35.7 \mathrm{a}$ & -13.22 & $6.2 \mathrm{a}$ & 48.95 \\
\hline 12 & $30.7 \mathrm{a}$ & 2.63 & 20.4 a & 35.14 \\
\hline 13 & $34.3 \mathrm{a}$ & -8.81 & $20.0 \mathrm{a}$ & 36.52 \\
\hline $\mathrm{CV}(\%)$ & 14.28 & - & 17.87 & - \\
\hline \multicolumn{5}{|c|}{ L. sativa } \\
\hline Control & $3.7 \mathrm{a}$ & - & $1.7 \mathrm{a}$ & - \\
\hline 1 & $2.9 \mathrm{a}$ & 20.35 & $1.1 \mathrm{a}$ & 38.86 \\
\hline 12 & $3.2 \mathrm{a}$ & 14.01 & $1.1 \mathrm{a}$ & 34.73 \\
\hline 13 & $3.1 \mathrm{a}$ & 15.34 & $1.2 \mathrm{a}$ & 30.83 \\
\hline $\mathrm{CV}(\%)$ & 24.13 & - & 26.73 & - \\
\hline \multicolumn{5}{|c|}{ D. tortuosum } \\
\hline Control & $6.1 \mathrm{a}$ & - & $2.1 \mathrm{a}$ & - \\
\hline 1 & $5.8 \mathrm{a}$ & 5.14 & $1.9 \mathrm{a}$ & 6.74 \\
\hline 12 & $6.7 \mathrm{a}$ & -9.19 & $1.8 \mathrm{a}$ & 10.87 \\
\hline 13 & $5.3 \mathrm{a}$ & 12.99 & $2.0 \mathrm{a}$ & 3.50 \\
\hline $\mathrm{CV}(\%)$ & 22.44 & - & 32.83 & - \\
\hline \multicolumn{5}{|c|}{ E. heterophylla } \\
\hline Control & $6.7 \mathrm{ab}$ & - & $1.1 \mathrm{a}$ & - \\
\hline 1 & $4.8 \mathrm{~b}$ & 29.31 & $1.0 \mathrm{a}$ & 7.54 \\
\hline 12 & $5.5 \mathrm{~b}$ & 18.81 & $1.2 \mathrm{a}$ & -0.96 \\
\hline 13 & $4.9 \mathrm{~b}$ & 27.15 & $0.9 \quad \mathrm{a}$ & 10.13 \\
\hline $\mathrm{CV}(\%)$ & 18.40 & - & 23.46 & - \\
\hline \multicolumn{5}{|c|}{ H. suaveolens } \\
\hline Control & $2.0 \mathrm{a}$ & - & 0.6 a & - \\
\hline 1 & $1.7 \mathrm{a}$ & 7.67 & $0.3 \mathrm{~b}$ & 57.44 \\
\hline 12 & $1.8 \mathrm{a}$ & 4.67 & $0.2 \mathrm{~b}$ & 69.19 \\
\hline 13 & $1.9 \mathrm{a}$ & 0.46 & $0.4 \mathrm{~b}$ & 48.93 \\
\hline $\mathrm{CV}(\%)$ & 21.59 & - & 32.91 & - \\
\hline
\end{tabular}

*Means, in the same column, with the same letter are not significantly different at $\mathrm{P}=0.05 \%$ by Tukey's test.

L. sativa and $H$. suaveolens a reduction in the roots size and also on the number of secondary roots was observed.

From the results obtained it was clear that the unsaturation on the side chain of sorgoleone is not essential for the biological activity. Also, small variation on the quinone structure (shorter side chain and acetoxy group on carbon 3) did not have a significative effect on the biological activity, compared with sorgoleone.

In conclusion, the chemistry described could be explored for the preparation of novel quinones with potential use as herbicides.

\section{ACKNOWLEDGMENTS}

We thank the Brazilian Agencies: Conselho Nacional de Desenvolvimento Científico e Tecnológico (CNPq), for a research fellowships (LCAB) and a research grant (CNPq/ PADCT); Coordenação de Aperfeiçoamento de Pessoal de Nível Superior (CAPES) for a MSc studentship (MLF) and Fundação de Amparo à Pesquisa do Estado de Minas Gerais (FAPEMIG) for financial support. We are also very grateful Prof. Francisco Affonso Ferreira from the Department Plant Science (UFV) for helping us with the biological assays.

\section{REFERENCES}

1. Overland, L.; Am. J. Bot. 1966, 53, 441.

2. Putnam, A. R.; DeFrank, J.; Barnes, J. P.; J. Chem. Ecol. 1983, 8, 1001.

3. Ben-Hammouda, M.; Kremer, R. J.; Minor, H. C.; Crop Science 1995, 35, 1652.
4. Bem-Hammouda, M.; Kremer, R. J.; Minor, H. C.; Sarwar M.; J. Chem. Ecol. 1995, 21, 775.

5. Abdul-Wahab, A. S.; Rice E. L.; Bull. Torrey Bot. Club 1967, 94, 486.

6. Guenzi, W. D.; McCalla T. M.; Soil Sci. Soc. Amer. Proc. 1962, 26, 456.

7. Netzly, D. H.; Butler, L.G.; Crop Science 1986, 26, 775.

8. Netzly, D. H.; Riopel, J. L.; Ejeta, G.; Butler, L.G.; Weed Science 1988, 36, 441.

9. Chang, M.; Netzly, D. H.; Butler, L.G.; Lynn, D. G.; J. Am. Chem. Soc. 1986, 108, 7858.

10. Einhellig, F. A.; Souza, I. F.; J. Chem. Ecol. 1992, $18,1$.

11. Rasmussen, J. A.; Hejl, A. M.; Einhelig, F. A.; Thomas, J. A.; J. Chem. Ecol. 1992, 18, 197.

12. Einhellig, F. A.; Rasmussen, J. A.; Hejl, A. M.; Souza, I. F.; J. Chem. Ecol. 1993, 19, 369.

13. Gonsalez, V. M.; Kazimir, J.; Nimbal, C.; Weston, L. A.; Cheniae, G. M.; J. Agric. Food Chem. 1997, 45, 1415.

14. Perrin, D. D.; Armarego, W. L. F.; "Purification of Laboratory Chemicals" Pergamon Press, Oxford, England, 1988.

15. Mancuso, A. J.; Swern, D.; Huang, S.; J. Org. Chem. 1978, 43, 2480.

16. Hua, D.H.; J. Am. Chem. Soc. 1986, 108, 3835.

17. Utermoehlen, C. M.; Singh, M.; Lehr, R. E.; J. Org. Chem. 1987, 52, 5574.

18. Brown, C.; Brown, H. C.; J. Am. Chem. Soc. 1969, 31, 3989.

19. MacLamore, W. M.; J. Am. Chem. Soc. 1951, 73, 2221.

20. Almeida, W. P.; Correia, C. R. A.; Tetrahedron Lett. 1994, 35, 1367. 